\title{
The winter browse supply for moose in different forest site-types in the Biebrza Valley, Poland
}

\author{
Anetta BORKOWSKA and Agnieszka KONOPKO
}

\begin{abstract}
Borkowska A. and Konopko A. 1994. The winter browse supply for moose in different forest site-types in the Biebrza Valley, Poland. Acta theriol. 39: 67-71.

The winter biomass of browse for moose was estimated in the fresh pine forest, the moist coniferous forest and the alder wood in the Biebrza Valley (NE Poland). Fifteen species of trees and shrubs were available to moose in the forest site-types examined. Ten of them were identified to be important: six in each forest association. On the basis of their biomass, Betula pubescens, B. pendula and Frangula alnus were the most important food plants in coniferous forests and Sorbus aucuparia in the alder wood. The highest supply of browse was found in the timber stand of the moist coniferous forest $(27.42 \mathrm{~kg}$ dry wt/ha) and the alder wood $(25.97 \mathrm{~kg}$ dry wt/ha). The lowest supply of $5.43 \mathrm{~kg}$ dry wt/ha was available in the fresh pine forest. Browse was least abundant in the pole-sized stands of both fresh pine $(0.78 \mathrm{~kg}$ dry wt/ha) and the moist coniferous forest $0.87 \mathrm{~kg}$ dry wt/ha).
\end{abstract}

Institute of Biology, Warsaw University, Branch in Białystok, ul. Świerkowa 20B, 15-950 Białystok, Poland

Key words: Alces alces, browse supply, the Biebrza Valley, Poland

\section{Introduction}

The Biebrza Valley is the main concentration area of the moose Alces alces (Linnaeus, 1758) in Poland. It supports moose population of 500-600 animals on 170000 ha in 1989-1991 (Gębczyńska and Raczyński 1993). Spatial distribution, population structure and social organization and habitat preference of moose have been described by Gębczyńska and Raczyński (1983, 1984, 1989). However, the winter food resources for moose in winter have not been estimated in forests of the Biebrza Valley until now. Pine forests with rich undergrowth on mineral soils and bog alder forest were the main moose winter habitats (Gębczyńska and Raczyński 1983, Fedyk et al. 1984). Therefore, we used those biotops in our study.

The purpose of the present investigation was: (1) to establish a list of the most important plant species which could compose a potential winter food resource in various forest site-types in the Biebrza Valley and (2) to estimate of the browse supply for moose in those environments.

\section{Study area and methods}

The studies were carried out in the central part of the southern basin of the Biebrza Valley (NE Poland, $53^{\circ} 21^{\prime} \mathrm{N}, 22^{\circ} 38^{\prime} \mathrm{E}$ ). The southern basin covers the area of 40000 ha with the forest area of 
6800 ha (Bosiak 1991). The moose winter density was estimated at 3.1-5.0 animals per 1000 ha (Gębczyńska and Raczyński 1983). The study areas included: (1) the fresh pine forest (Vaccinio myrtilli-Pinetum typicum), (2) the moist coniferous forest (Vaccinio myrtilli-Pinetum molinietosum) and (3) the alder wood (Carici elongatae-Alnetum typicum) (Czerwiński 1978).

Dzięciołowski (1969) defined browse as shoots on trees and shrubs from the previous growing season within the zone from the ground (or snow) surface to the height of $2 \mathrm{~m}$. We observed moose contacts on trees from 0.5 to $3.5 \mathrm{~m}$ high, so we took six tree height classes in our study: class I: 0.5-0.99 m, class II: $1.0-1.49$ m, class III: $1.5-1.99$ m, class IV: $2.0-2.49$ m, class V: $2.5-2.99$ m, class VI: $3.0-3.49 \mathrm{~m}$.

The studies were carried out in 1989, 1990 and 1992, after the end of the vegetation period (September-October). The plot method with clipping shoots was used (Dzięciołowski 1969, Bobek and Dzięciołowski 1972, modified). Four hundred unfenced plots $(2 \times 5 \mathrm{~m}$ each) were distributed systematically along the transects in three forest site-types.

The amount of browse were estimated for 10 species because others were too rare to be included. The number of trees was recorded for each plot in six tree height classes. The browse was clipped from 1130 trees growing on the plots and weighed to $0.1 \mathrm{~g}$. Clipped samples were dried during 48 hours at $65^{\circ} \mathrm{C}$ and reweighed with the same accuracy (Dzięciołowski 1969). Coefficients W (i.e. dry matter/fresh matter of sample) were used to calculate average dry matter of browse per stem and plot.

Differences in browse supply among types of forest were tested using Kruskal-Wallis one-way analysis by ranks because data were not normally distributed ( $p>0.05$ in $\chi^{2}$-test). Kruskal-Wallis analysis was also used to test the differences in biomass production among browse species and tree height classes.

\section{Results}

Ten species of trees and shrubs constituted the basis of winter browse supply in the studied forests of the Biebrza Valley (Table 1). The others, like Pinus sylvestris, Juniperus communis, Corylus avellana, Viburnum opulus were too rare

Table 1. Winter browse production (kg dry wt/ha \pm SD) of browse species examined in forest site-types, the Biebrza Valley, Poland. $p$ - significance level in Kruskal-Wallis test, ns - not significant $(p \geq 0.05)$.

\begin{tabular}{|c|c|c|c|c|c|}
\hline \multirow{2}{*}{ Browse species } & \multicolumn{2}{|c|}{ Fresh pine forest } & \multicolumn{2}{|c|}{ Moist coniferous forest } & \multirow{2}{*}{$\frac{\text { Alder wood }}{\text { Timber stand }}$} \\
\hline & Pole-sized stand & Timber stand & Pole-sized stand & Timber stand & \\
\hline Betula pendula & $0.40 \pm 2.14$ & $0.71 \pm 3.13$ & $0.01 \pm 0.14$ & $2.17 \pm 4.37$ & - \\
\hline Betula pubescens & $0.10 \pm 0.58$ & $2.73 \pm 7.10$ & $0.27 \pm 1.06$ & $10.43 \pm 9.56$ & $1.82 \pm 1.77$ \\
\hline Alnus glutinosa & - & - & - & - & $0.98 \pm 3.26$ \\
\hline Quercus spp. & $0.21 \pm 0.84$ & $0.58 \pm 3.13$ & $0.28 \pm 0.70$ & $1.30 \pm 3.39$ & - \\
\hline Populus tremula & - & $0.09 \pm 0.62$ & $0.01 \pm 0.08$ & $0.13 \pm 0.48$ & - \\
\hline Salix spp. & - & $0.01 \pm 0.14$ & $0.05 \pm 0.28$ & $2.52 \pm 7.34$ & - \\
\hline Ribes spp. & - & - & - & - & $3.58 \pm 4.77$ \\
\hline Sorbus aucuparia & - & - & - & - & $8.78 \pm 10.86$ \\
\hline Padus avium & - & - & - & - & $4.15 \pm 11.94$ \\
\hline Frangula alnus & $0.08 \pm 0.39$ & $1.31 \pm 3.24$ & $0.25 \pm 0.67$ & $10.87 \pm 13.45$ & $6.66 \pm 7.60$ \\
\hline$p<$ & ns & 0.0001 & 0.0001 & 0.0001 & 0.0001 \\
\hline
\end{tabular}


or their heights were lower than $0.5 \mathrm{~m}$. On the other hand, we did not observe moose feeding on Picea excelsa in the forests of the Biebrza Valley.

Biomass production of some browse species differed in relation to forest site-type: $p<0.05$ in Kruskal-Wallis test for Betula pendula and Frangula alnus in pole-sized stands and B. pendula, B. pubescens, Quercus spp. and $F$. alnus in timber stands (Table 1).

Browse species produced more biomass of twigs ( $p<0.05$, Kruskal-Wallis test) in the timber stands than in the pole-sized stands, both in the fresh pine forest (B. pubescens and $F$. alnus) and in the moist coniferous forest (B. pendula, B. pubescens, Salix spp., F. alnus) (Table 1).

Table 2. Winter browse supply in the tree stands of different forest site-types (kg dry wt/ha $\pm \mathrm{SD}$ ), the Biebrza Valley, Poland. $p$ - significance level in Kruskal-Wallis test, $\mathrm{ns}$ - not significant $(p \geq 0.05)$.

\begin{tabular}{lccc}
\hline Forest site-type & Pole-sized stand & Timber stand & $p<$ \\
\hline Fresh pine forest & $0.78 \pm 2.37$ & $5.43 \pm 10.18$ & 0.001 \\
Moist coniferous forest & $0.87 \pm 1.72$ & $27.42 \pm 20.47$ & 0.0001 \\
Alder wood & - & $25.97 \pm 22.11$ & - \\
$p<$ & ns & 0.0001 & \\
\hline
\end{tabular}

Fig. 1. The winter browse supply in six tree height classes in the pole-sized stand (a) and the timber stand (b) of different forest site-types; the Biebrza Valley, Poland. FPF - fresh pine forest, MCF - moist coniferous forest, AW - alder wood. Significance levels in Kruskal-Wallis test are given above the bars, ns - not significant difference $(p \geq 0.05), * * * *-p<0.0001$, $*-p<0.05$.

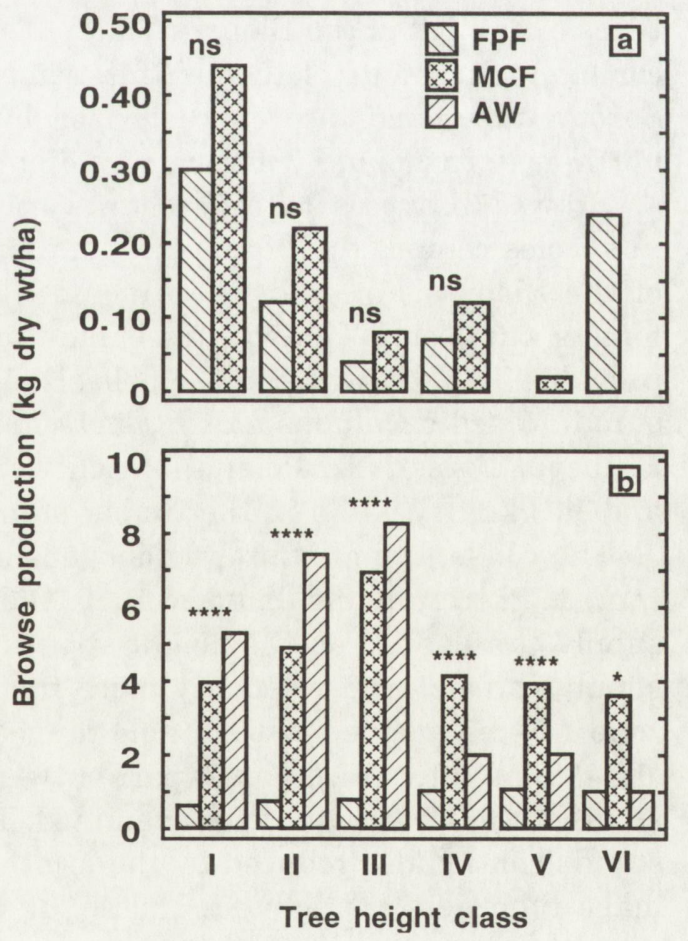


The browse supply varied between stands (Table 2). The pole-sized stands provided less biomass of browse than the timber stands in the fresh pine $(H=$ $12.40, p<0.001)$ and in the moist coniferous forest $(H=92.12, p<0.0001)$. Pole-sized stands examined produced similar browse supply $(H=2.84$, ns). On the other hand, the timber stand of the fresh pine forest had about one fifth of browse supply available to moose in the other timber stands. The timber stand of the alder wood had similar browse supply to the moist coniferous forest $(H=0.29$, ns) (Table 2).

Browse production differed in relation to tree height classes $(p<0.001$, Kruskal-Wallis test for each forest site-type). In the timber stands only we found significant differences ( $p<0.05$, Kruskal-Wallis test) in the amount of browse available in tree height classes among forest types (Fig. 1). The highest classes (IV, V and VI), the most suitable to moose, produced more biomass of twigs than lower ones only in the timber stand of the fresh pine forest (Fig. 1b).

\section{Discussion}

Moose diet composition is characterized by a high variability which depends on the habitat and geographical distribution of the species (Peterson 1955, Joyal 1976, Dunin and Januško 1979, Cederlund et al. 1980, and others). The results obtained suggest that species diversity of the browse is rather low in the forest types examined in the Biebrza Valley. Ten species are important because they are common. Only four of them (Betula pubescens, B. pendula, Frangula alnus and Sorbus aucuparia) are characterized by a high production. In other forests of north-eastern Poland winter moose diet consists of 16 tree species (Morow 1976).

Browse resources are different in various forest site-types because of differences in species composition, frequency, site productivity and earlier browsing. Forests of the Biebrza Valley have rather low browse supply in comparison with other forests studied in Poland. Fresh pine forest (Peucedano-pinetum) in SE Poland provides $3 \mathrm{~kg}$ dry wt/ha in the pole-sized stand and $26 \mathrm{~kg}$ dry wt/ha in the timber stand. Mixed deciduous forest (Querceto-Betuletum serratuletosum) in Białowieża Primeval Forest, NE Poland, is richer: $551 \mathrm{~kg}$ dry wt/ha in the pole-sized stand and $149 \mathrm{~kg}$ dry wt/ha in the timber stand (Bobek et al. 1975).

The consumption of browse depends on the height or age of food plant (Bobek et al. 1972, Dunin and Januško 1979, Oldemeyer 1983). Therefore, the real browse supply can depend on the height structure of food plants. Areas with low browse supply can be used relatively more frequently if twigs are available within the zone 1.5-3.5 m, the most suitable to moose. However, the top tree height classes (1.5-3.5 m) offer the greatest part of twig production (51-75\%) only in the timber stand of the forest site-types examined. The small browse supply of the pole-sized stands can be also reduced by the location on the lower trees $(0.5-1.49 \mathrm{~m})$ which make them less attractive to moose. 
Browse resources of older forest stands are also poorer in comparison with younger stands (up to $3.2 \mathrm{t}$ dry wt/ha in thicket of the fresh pine forest - Borkowska and Konopko 1994). However, older stands occupy about $77 \%$ of the total forest area of the Biebrza Valley (Bosiak 1991). On the other hand, pine and bog alder forests together with willow-birch shrubs compose the major winter feeding grounds for moose and other deer species in the southern Biebrza basin (Fedyk et al. 1984).

Acknowledgement: We would like to thank to Prof M. Gębczyński for his attention to our work and critical reading of the manuscript. We are also grateful to Dr M. Konarzewski for his linguistic corrections.

\section{References}

Bobek B., Borowski S. and Dzięciołowski R. 1972. Browse supply in various forest ecosystems. Pol. ecol. Stud. 1: 17-32.

Bobek B. and Dzięciołowski R. 1972. Method of browse estimation in different types of forest. Acta theriol. 17: 171-186.

Borkowska A. and Konopko A. 1994. Moose browsing on pine and willow in the Biebrza Valley, Poland. Acta theriol. 39: 73-82.

Bosiak A. 1991. Charakterystyka przyrodnicza i gospodarcza lasów Kotliny Biebrzańskiej. Zesz. probl. Post. Nauk roln. 372: 521-535.

Cederlund G., Ljungqvist H., Markgren G. and Stålfelt F. 1980. Foods of moose and roe deer at Grimsö in Central Sweden - results of rumen content analysis. Viltrevy 11: 169-247.

Czerwiński A. 1978. Zbiorowiska leśne północno-wschodniej Polski. Zesz. nauk. Polit. Bialost. 27: $5-326$.

Dunin V. F. and Januško A. D. 1979. Ocenka kormovoj bazy losja v lesnych ugod’jah. Uradžaj, Minsk: 1-94. [In Russian]

Dzięciołowski R. 1969. Metody pomiaru zapasu żeru pędowego w zbiorowiskach leśnych. Ecol. pol. B. 15: $255-261$.

Fedyk S., Gębczyńska Z., Pucek M., Raczyński J. and Sikorski M. D. 1984. Winter penetration by mammals of different habitats in the Biebrza Valley. Acta theriol. 29: 317-336.

Gębczyńska Z. and Raczyński J. 1983. Habitat use by moose in the Biebrza river valley. Proc. 16th IUGB Congr. Vysoké Tatry, Šterbské Pleso, ČSSR: 43-49. [In Russian with English summary]

Gębczyńska Z. and Raczyński J. 1984. Habitat preferences and population structure of moose in the Biebrza river valley. Acta zool. Fenn. 172: 93-94.

Gębczyńska Z. and Raczyński J. 1989. Distribution, population structure and social organization of moose in the Biebrza Valley, Poland. Acta theriol. 34: 195-217.

Gębczyńska Z. and Raczyński J. 1993. Problems of protection and management of moose and other game in the Biebrza National Park. Parki Narodowe i Rezerwaty Przyrody 12: 5-36. [In Polish with English summary]

Joyal R. 1976. Winter foods of moose in La Vérendrye Park, Québec: an evaluation of two browse survey methods. Can. J. Zool. 54: 1765-1770.

Morow K. 1976. Food habits of moose from the Augustów Forest. Acta theriol. 21: 101-116.

Oldemeyer J. L. 1983. Browse production and its use by moose and snowshoe hares at the Kenai Moose Research Center, Alaska. J. Wildl. Manage. 47: 486-496.

Peterson R. L. 1955. North American moose. University of Toronto Press, Toronto: 1-280.

Received 23 April 1993, accepted 5 February 1994. 